ACTA AGROBOTANICA

Vol. 62 (2): 149-154

2009

\title{
Bunias orientalis L. AS A NATURAL OVERWINTERING HOST OF Turnip mosaic virus
}

\author{
Tadeusz Kobyłko, Zbigniew Maj, Zbigniew Gajewski \\ Department of Botany, Faculty of Horticulture, Agricultural University in Kraków, \\ 29 Listopada 54, 31-425 Kraków, Poland \\ e-mail: zbotaniki@ogr.ar.krakow.pl
}

Received: 28.05.2009

\section{Abstract}

A virus was isolated, using mechanical inoculation, from hill mustard (Bunias orientalis L.) plants exhibiting yellow mottling and blistering on leaves, which were frequently accompanied by asymmetric leaf narrowing. It systemically infected certain plants from the family Brassicaceae (Brassica rapa, Bunias orientalis, Hesperis matronalis, Sinapis alba) as well as Cleome spinosa and Nicotiana clevelandii, and locally Atriplex hortensis, Chenopodium quinoa, Ch. amaranticolor, $N$. tabacum. In the sap, it maintained infectivity for 3-4 days and lost it after heating for $10 \mathrm{~min}$. at a temperature of $55-60^{\circ} \mathrm{C}$ or when diluted with water at $10^{-3}$. Virus particles were thread-like with a length of $675-710 \mathrm{~nm}$. Based on an analysis of biological properties of the pathogen, serological response, particle morphology and data from field observations, it was identified as an isolate of Turnip mosaic virus (TuMV), and hill mustard was recognised as a natural overwintering host for this pathogen.

Key words: leaf malformation, yellow mottling, leaf narrowing, blistering

\section{INTRODUCTION}

Hill mustard (Bunias orientalis L.) is a herbaceous plant of the cabbage family - Brassicaceae (syn. crucifers - Cruciferae), which grows up to a height of $2 \mathrm{~m}$ (Fig. 1). It is treated as a biennial or perennial (B i r n b a u m, 2006). It has been recognised to be an invasive alien species due to its strong expansion from south-eastern Europe to the west and north, in particular over the last thirty years (D i e t z et al. 1999). It is currently found in all countries of central Europe, in a large part of western and northern Europe as well as in North America (B i r n b a u m , 2006). In Poland it is widespread across the whole country. ( $\mathrm{Z}$ a j a c and $\mathrm{Z} \mathrm{a} \mathrm{j} \mathrm{ą} \mathrm{c} \mathrm{,} \mathrm{2001).} \mathrm{It} \mathrm{mostly} \mathrm{occupies} \mathrm{anthropogenic}$ habitats on calcareous substrate, such as roadsides, railway embankments, landfills, debris disposal sites and worked-out quarries (Pi ękoś-M irkow a, 2002; T ok a r s k - G u zik et al. 2005), frequently forming dense populations. K o m p a ł a - B ą b a et al. (2005) presented phytosociological approach of communities with the participation of Bunias orientalis. This kenophyte also penetrates into semi-natural communities, and even into specially protected areas such as, e.g., national parks (M i c h a l i k, 1978; P i ę k o ś Mirk ow a, 2002). Plants of this species have been the objects of research, primarily geobotanical and population studies, and incidentally phytopathological studies. An example of the latter is a paper of $\mathrm{Li} \mathrm{h}$ nell (1951) from Sweden who found hill mustard exhibiting leaf mosaic as a result of infection with Cucumber mosaic virus (CMV).

During research on the spread of the hill mustard population from the grounds of the former Nazi concentration camp in Kraków - Płaszów to green areas of a housing estate located nearby, extremely severe symptoms of yellow mottling and leaf malformation in the form of blistering and asymmetric leaf narrowing were observed in over a dozen individuals of this species growing in the edge zone of the population (Fig. 2). It was thought that they could be an effect of virus infection, therefore a study was carried out in order to explain the reason for the development of these symptoms. This paper presents the results of this study.

\section{MATERIALS AND METHODS}

The plant material used to isolate the pathogen comprised young leaves sampled from one hill mustard plant exhibiting characteristic disease symptoms. The leaves were used to prepare, by grinding them in a small amount of phosphate buffer, a homogenisate with which indicator plants were inoculated. These 
plants were as follows: Chenopodium quinoa, Nicotiana clevelandii, N. tabacum 'Xanthi', Brassica rapa. The isolated virus was maintained and propagated in systemically responding plants of $N$. clevelandii and $B$. rapa. The sap from these plants was used to inoculate the test plants and to examine the stability of the virus in the sap. In the biological test, reisolations were made to Ch. quinoa plants from leaves of the plants in which after inoculation no disease symptoms had occurred, or only local symptoms. The morphology of virus particles was examined using a Tesla electron microscope. Slides for examination were prepared from leaf tissue of systemically infected plants of $N$. clevelandii, by means of the deep method, using phosphotungstic acid to stain the solution. Particle measurements were performed on electronograms. In order to verify the results of the phase designed to identify the pathogen and to examine the presence of Turnip mosaic virus (TuMV) in hill mustard plants growing in field conditions, serological investigations were carried out using the DAS - ELISA method. In these tests, anti-TuMV polyclonal antibodies were used (cat. No. 07049 manufactured by Loewe). Hill mustard leaves, sampled from 12 specimens growing in field which exhibited disease symptoms and from 3 specimens with no disease symptoms, were the source of antigens. Loewe I buffer was used for extraction $(2 \mathrm{ml}$ per $0.2 \mathrm{~g}$ of leaf tissue). The tests were performed on Nunc MaxiSorp plates. The absorbance was measured at $405 \mathrm{~nm}$ using a multiscan photometer (Labsystem Multiscan MS).

\section{RESULTS}

The pathogen was isolated by transferring it without difficulty with the sap of the diseased hill mustard plant to Chenopodium quinoa, Nicotiana tabacum 'Xanthi', N. clevelandii, Brassica rapa plants, which was evidenced by the symptoms that appeared on these plants after their inoculation.

The indicator plants used at this stage of the investigations responded to mechanical inoculation with the isolated pathogen as follows:

From the cabbage family:

Brassica napobrassica - no symptoms. Negative result of reisolation.

Brassica rapa - local chlorotic spots, systemic mosaic and leaf deformation, growth inhibition.

Brassica oleracea var. capitata - no symptoms. Negative result of reisolation.

Bunias orientalis - local spreading chlorotic spots, and subsequently severe systemic response in the form of yellow mottling and blistering as well as deformation of young growing leaves. Low efficiency of infections ( 3 infected plants out of 14 inoculated ones).
Hesperis matronalis - local chlorotic spots, severe systemic mottling, blister-like protuberances and leaf blade deformation.

Mathiola incana - no symptoms. Negative result of reisolation.

Sinapis alba - systemic mosaic and growth inhibition.

From other families:

Atriplex hortensis - local necrotic spots, no systemic symptoms. Negative result of reisolation.

Chenopodium quinoa - local necrotic spots, no systemic symptoms. Negative result of reisolation.

Cleome spinosa - local chlorotic spots, systemic stem streaking, growth inhibition.

Cucumis sativus 'Monastyrski' - no symptoms. Negative result of reisolation.

Nicotiana clevelandii - local chlorotic and necrotic spots, systemic mosaic, and subsequently necrotisation of leaf blades progressing from the leaf base, leading to the death of whole plants.

$N$. glutinosa - no symptoms. Negative result of reisolation.

$N$. tabacum 'Xanthi' and 'Samsun' - local necrotic spots, no systemic symptoms. Negative result of reisolation.

The traits determining the stability of the isolated virus in the sap from $N$. clevelandii plants are as follows: longevity in vitro (LIV) $4-5$ days, thermal inactivation point (TIP) $55-60^{\circ} \mathrm{C}$, dilution end point (DEP) $10^{-4}$.

The virus particles observed and measured on electronograms were thread-like, with a length of ranging from 675 to $710 \mathrm{~nm}$ (Fig. 3).

The results of the DAS - ELISA serological test are collected in Tab. 1. Field observations of the diseased hill mustard specimens, carried out for four successive growing seasons, showed that every year disease symptoms, similar to the previous year's symptoms, appeared on leaves in the same individuals; these symptoms were particularly severe in the spring period, becoming milder with time. In each of these plants, the presence of Turnip mosaic virus was detected using a serological test.

\section{DISCUSSION}

The results of the biological and serological tests, as well as the particle morphology of the isolated pathogen, form the basis for identifying it as Turnip mosaic virus (TuMV). In terms of stability in sap, it meets the criteria described in the characteristics of TuMV given by Tomlinson (1970), and it was similar to Polish TuMV isolates obtained from rutabaga (B łaszczak, 1976; Kobyłko and Maj, 1989), horseradish (Twardowicz-Jakusz et 
Table 1

Results of the DAS ELISA serological test for the presence of TuMV in hill mustard plants covered by the study.

\begin{tabular}{|c|c|c|}
\hline Sample & \multicolumn{2}{|c|}{$\begin{array}{l}\text { Absorbance value at } 405 \mathrm{~nm} \\
\text { (for two wells) }\end{array}$} \\
\hline Positive control & 2.718 & 2.875 \\
\hline Negative control & 0.010 & 0.012 \\
\hline Hill mustard with symptoms no. 1 & 587 & 2.743 \\
\hline no. 2 & 1.673 & 1.725 \\
\hline no. 3 & 1.971 & 2.112 \\
\hline no. 4 & 1.343 & 1.314 \\
\hline no. 5 & 2.176 & 2.130 \\
\hline no. 6 & 2.327 & 2.467 \\
\hline no. 7 & 1.054 & 1.017 \\
\hline no. 8 & 1.139 & 1.141 \\
\hline no. 9 & 0.511 & 0.357 \\
\hline no. 10 & 0.456 & 0.366 \\
\hline no. 11 & 0.453 & 0.324 \\
\hline no. 12 & 0.822 & 0.641 \\
\hline Hill mustard without symptoms no. 1 & 0.019 & 0.020 \\
\hline no. 2 & 0.016 & 0.017 \\
\hline no. 3 & 0.006 & 0.009 \\
\hline
\end{tabular}

al. 1977), carrot (T w a r d o w i c z - J a k u s z, 1979), poppy (Przy b y lska, 1991). The thread-like shape of particles of the isolated pathogen and their length, being within a range of 675-710 nm, may be assessed as traits matching Turnip mosaic virus ( $\mathrm{T}$ o $\mathrm{m} \mathrm{l}$ i n s o $\mathrm{n}$, 1970; Provvidenti, 1981). The trait in which the investigated isolate clearly differs from the abovementioned TuMV isolates is a narrower range of plants susceptible to infection than in their case, since it did not infect certain Brassicaceae plants, such as: Brassica oleracea var. capitata, Brassica oleifera, Brassica napobrassica, Mathiola incana. This trait, used as a criterion applied by M c D on a ld and $\mathrm{Hi}$ ebert (1975) to distinguish two types among TuMV isolates, allows this isolate to be recognised as type II. The isolates which can infect all Brassica species are classified by these authors as type I, whereas the isolates which infect only some cabbage species and do not generally infect Brassica oleracea are included in type II. In the analysis of plant responses used to identify the isolated pathogen, also worth noticing is the fact that it did not infect, similarly to an isolate from Hesperis (Kobyłko and Maj, 1991), Nicotiana glutinosa plants, hence, a species which is mentioned as the one which is susceptible to systemic infection by TuMV ( $\mathrm{S} \mathrm{mith,} \mathrm{1972)} \mathrm{and} \mathrm{which} \mathrm{is} \mathrm{recommended} \mathrm{for} \mathrm{its}$ propagation (T o m li n s o n, 1970; Provvidenti, 1981). It may attest to significant dissimilarity relative to other TuMV isolates or raise certain identification doubts. This specific biological trait of the isolated virus should be assessed in the context of the statement that TuMV isolates differ markedly in terms of virulence and test plant responses, the consequence of which is a large number of strains identified in different regions of the world ( $\mathrm{S} \mathrm{h} \mathrm{u} \mathrm{k} \mathrm{la} \mathrm{et} \mathrm{al.} \mathrm{1994).}$

The results of the serological test, in which absorbance readings for the test samples were only slightly lower than readings for positive controls (Tab. 1), ultimately confirmed the diagnosis that hill mustard was infected by TuMV.

The systemic infection symptoms, which had developed in the hill mustard plants experimentally inoculated with the isolated pathogen, were similar to the symptoms observed in the individuals growing in a natural stand. It allows TuMV to be identified as the casual agent of yellow mottling of leaves, blistering 


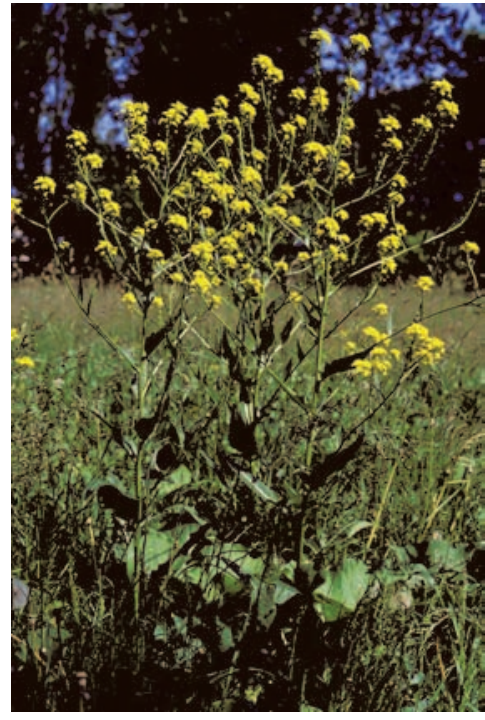

Fig. 1. Hill mustard in a natural stand.

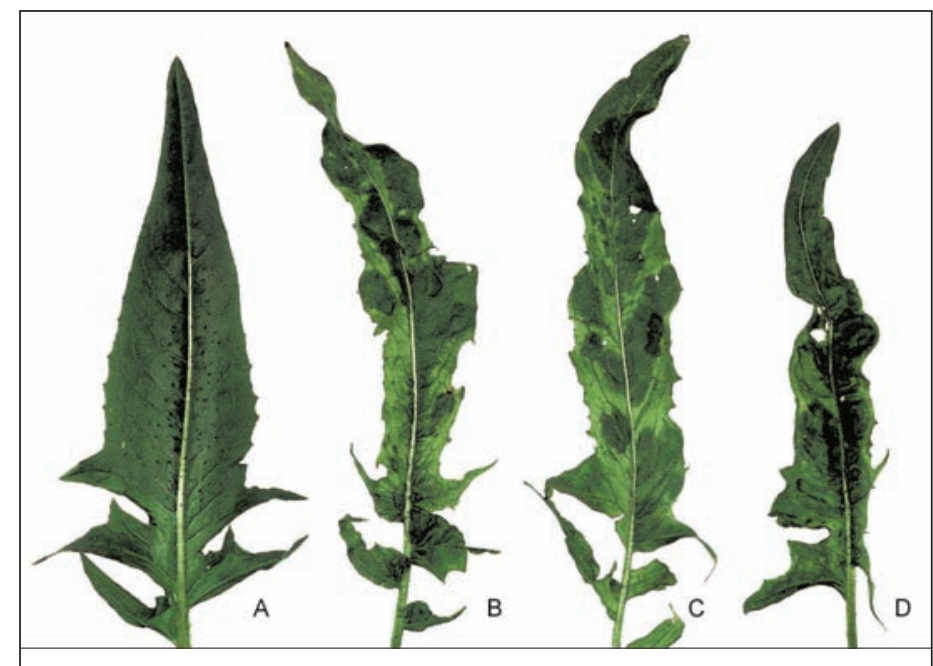

Fig. 2. Hill mustard leaves. A - from an uninfected plant. B, C, D - from naturally TuMV-infected plants.

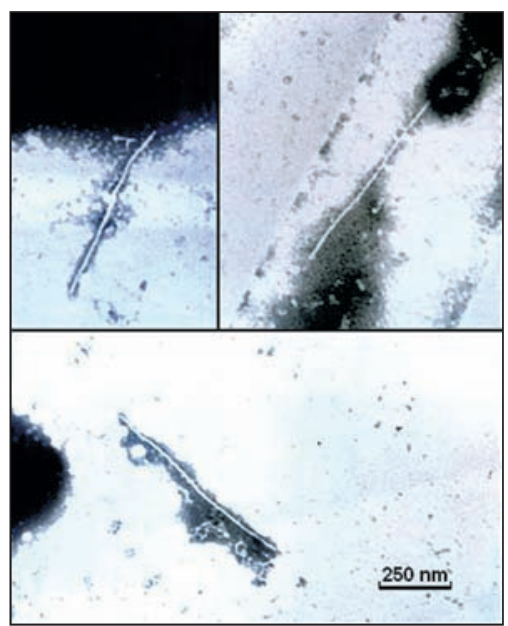

Fig. 3. TuMV in the sap of infected Bunias orientalis specimens. 
and leaf narrowing. The appearance in spring of leaves with characteristic disease symptoms in the same specimens as in the previous year and the detection of TuMV in them prove that this pathogen survived the winter in the underground organs. It gives the basis for classifying hill mustard plants as natural overwintering hosts of Turnip mosaic virus. The longevity of hill mustard, reaching up to 12 years (D i e $\mathrm{z}$ and $\mathrm{S} t \mathrm{e}$ i $\mathrm{n}$ le i n, 1998), makes this species a potentially dangerous host of TuMV, since infected individuals can be a source of infection threatening Brassica plants for many years.

\section{CONCLUSIONS}

1. The casual agent of yellow mottling, blistering and asymmetric leaf narrowing in hill mustard plants turned out to be a specific isolate of Turnip mosaic virus (TuMV), which infected only some Brassica plants.

2. Hill mustard should be classified as natural hosts of TuMV, which overwinter this pathogen.

3. TuMV-infected hill mustard plants can serve as reservoirs of the virus for many growing seasons, being a potential source of infection.

\section{REFERENCES}

B irnbaum C., 2006. NOBANIS - Invasive Alien Species Fact Sheet - Bunias orientalis. From: Online Database of the North European and Baltic Network on Invasive Alien Species - NOBANIS www.nobanis.org, date of access 22/04/2009.

B ł a s z c z a k W., 1976. Rozpoznanie kilku chorób wirusowych roślin w Polsce. / Diagnosis of several virus diseases in Poland. Roczn. Nauk Roln. 6 (2): 69-88.

Diet z H., S te in le in T., 1998. The impact of anthropogenic disturbance on life stage transitions and stand regeneration of the invasive alien plant Bunias orientalis L. [In:] U. Starfinger, K. Edwards, I. Kowarik, M. Williamson (eds): Plant invasions: Ecological mechanisms and human responses: 169-184, Backhuys, Leiden.

Dietz H., Steinlein T., U11mann I., 1999. Establishment of the invasive perennial herb Bunias orientalis L.: An experimental approach. Acta Oecologia, 20 (6): 621-632.

Kobyłko T., Maj Z., 1989. Identyfikacja wirusa mozaiki rzepy (Turnip mosaic virus) wyizolowanego z brukwi (Brassica napobrassica L.). / Identification of Turnip mosaic virus isolated from rutabaga (Brassica napobrassica L.). Acta Agr. Silv. ser. Agr. XXVIII: 19-23.

Kobyłko T., Maj Z., 1991. Some properties of an isolate of turnip mosaic virus (TuMV) from Hesperis matronalis L. Virus diseases of plants. Proceedings of the 20th Conference of Polish Plant Virologist. Warsaw, 22-23 October 1987: 49-56.
Kompała-Bąba A., Bąba W., Błońska A., 2005. Phytocenoses with Bunias orientalis L. on the anthropogenic habitats of the Cracow-Silesian Upland (Poland). Ecological impact and management. $8^{\text {th }}$ EMAPI Conference Proceedings. 5-12 September 2005, Katowice. Poland: 32.

Lihnel1 D., 1951. Några värdväxter för Cucumis-virus 1 i Sverige. Växtskyddsnotiser, 15 (4): 52-56.

Mc Donald J. G., Hiebert E., 1975. Characterization of the capsid and cylindrical inclusion proteins of three strains of turnip mosaic virus. Virology, 63: 295-303.

Mich a lik S., 1978. Rośliny naczyniowe Ojcowskiego Parku Narodowego. / Vascular plants of the Ojców National Park. Studia Nat. Ser. A. Wyd. Nauk. PAN. Zakł. Ochr. Przyr. 16. PWN Warszawa-Kraków: 63.

P i ę k oś- M i r k ow a H., 2002. Ekspansja rukiewnika wschodniego Bunias orientalis w Tatrzańskim Parku Narodowym. / Expansion of hill mustard (Bunias orientalis) in the Tatra National Park. Chrońmy Przyrodę Ojczystą, 58 (2): 112-114.

Provvidenti R., 1981. Turnip mosaic potyvirus. [In:] Brunt A. A., Crabtree K., Dallwitz M. J., Gibbs A. J. and Watson L. (eds). Viruses of Plants Descriptions and Lists from VIDE Database: 1340-1343.

Przybylska M., 1991. Turnip mosaic virus (TuMV) on $\mathrm{Pa}$ paver somniferum $\mathrm{L}$. in Poland. Virus diseases of plants. Proceedings of the 20th Conference of Polish Plant Virologist. Warsaw, 22-23 October, 1987: 57-62.

Shukla D. D., Ward C. W., B r unt A. A., 1994. Case histories of some Potyviruses in the Potyviridae. CAB International: 385-387.

S m it h K. M., 1972. A Textbook of Plant Virus Diseases. Longman. London: 556-560.

To m 1 in s on J. A., 1970. Turnip mosaic virus. C.M.I./A.A.B. Description of Plant Viruses 8.

Twardowicz-Jakusz A., Kaniewski W., D unajskaZielińska L., 1977. Badania diagnostyczne nad wirusami chrzanu. / Diagnostic studies on horseradish viruses. Zesz. Probl. Post. Nauk Roln. 195: 173-193.

Twardowicz-Jakusz A., Ziel ińska L., 1979. Badania nad wirozami pietruszki i marchewki. / Studies on viroses of parsley and carrot. Zesz. Probl. Post. Nauk Roln. 226: 71-87.

Zając A., Zając M., 2001. Atlas rozmieszczenia roślin naczyniowych w Polsce p. XII +714 . Pracownia Chorologii Komputerowej Instytutu Botaniki. Uniwersytet Jagielloński, Kraków. 
Rukiewnik wschodni (Bunias orientalis L.) naturalnym gospodarzem przezimowującym wirusa mozaiki rzepy (Turnip mosaic virus)

\section{Streszczenie}

$\mathrm{Z}$ roślin rukiewnika wschodniego (Bunias orientalis L.) wykazujących na liściach żółtą plamistość i pęcherzykowatość, którym często towarzyszyła niesymetryczna redukcja blaszek, wyizolowano, za pomocą mechanicznej inokulacji, wirusa. Zakażał on systemicznie niektóre rośliny z rodziny Brassicaceae (Brassica rapa, Bunias orientalis, Hesperis matronalis, Sinapis alba) oraz Cleome spinosa i $\mathrm{Ni}$ cotiana clevelandii, a lokalnie Atriplex hortensis, Chenopodium quinoa, Ch. amaranticolor, N. tabacum. W soku zachowywał infekcyjność przez 3-4 dni, tracil ją po podgrzaniu przez $10 \mathrm{~min}$. w temperaturze 55 $-60^{\circ} \mathrm{C}$ lub przy rozcieńczeniu wodą wynoszącym $10^{-3}$. Cząsteczki wirusa miały postać nitkowatą o długości od $675-710 \mathrm{~nm}$. Na podstawie analizy właściwości biologicznych patogena, reakcji serologicznej, morfologii cząstek oraz danych z obserwacji terenowych zidentyfikowano go jako izolat wirusa mozaiki rzepy TuMV, a rukiewnik wschodni uznano za naturalnego gospodarza przezimowującego tego patogena. 